\title{
Applying insights from the pharma innovation model to battery commercialization- pros, cons, and pitfalls
}

Eve D. Hanson, Department of Materials Science and Engineering, Northwestern University, Evanston, Illinois 60208, USA

Samir Mayekar, SiNode Systems, Chicago, Illinois 60616, USA

Vinayak P. Dravid, Department of Materials Science and Engineering, Northwestern University, Evanston, Illinois 60208, USA; and International Institute for Nanotechnology, Northwestern University, Evanston, Illinois 60208, USA Address all correspondence to Vinayak P. Dravid at v-dravid@northwestern.edu (Received 9 February 2017; accepted 27 July 2017)

\section{ABSTRACT}

\section{Lessons from the pharmaceutical industry's commercialization successes can be identified and applied to the U.S. battery industry to potentially improve its discouragingly low startup success rates.}

A carbon-neutral and sustainable society of the future necessitates the widespread use of battery technologies that are efficient, effective, and economical. Lower-cost and more energy-dense battery technology can help solve many of our energy challenges, such as balancing the intermittency problems of renewables and making possible electric transportation fleets. New advanced materials are crucial to such battery advances. However, bringing advanced energy materials to market in the United States remains a formidable challenge. Hurdles include high upfront capital requirements, long timelines to success, and few opportunities for technology risk-reduction. Such challenges impede startups from developing financially viable technologies. Consequently, recent advances in battery performance have come from incremental changes implemented by large companies. By contrast, the pharmaceutical industry has many similar technical challenges, yet has an established pipeline of U.S. startup successes. We review and compare the current market structures of battery and pharma innovation. We propose an updated model of U.S. battery commercialization, informed by the pharma model's successes. The new approach's benefits and potential pitfalls are discussed. We provide recommendations for entrepreneurs, investors, manufacturers, and policy makers to improve the battery innovation ecosystem. We hope that these ideas spur the battery community to more successfully commercialize and deploy transformative technologies.

Keywords: energy storage; sustainability; economics

\section{DISCUSSION POINTS}

- This paper focuses on improving the commercialization success rates for battery startups. How does Tesla's investments in a battery Gigafactory relate to the points in the paper?

- The pharmaceutical industry struggles with declining research productivity (defined as the number of new drugs per input research dollar). How does this affect the authors' proposals?

\section{Introduction}

Better batteries are critical to the world's clean energy future. Achieving more economical and efficient rechargeable energy storage $\left(<\$ 125\right.$ kilowatt-hour $\left.^{1}\right)$ would enable long-range electric vehicles (EVs) to economically compete with gasoline cars, ${ }^{2}$ a key step in electrifying transportation and reducing the transportation sector's $1 / 4$ share of U.S. $\mathrm{CO}_{2}$ emissions. ${ }^{3}$ Improved energy storage can help balance an intermittent electricity load, allowing more intermittent renewable energy generation sources to come online. ${ }^{4}$ Improving battery technology is instrumental to achieving these goals.

Rechargeable, energy-dense batteries were made possible in 1991, with the introduction of lithium-ion batteries by Sony. ${ }^{5}$ The lithium-ion battery's rechargeable nature and eventual higher energy density allowed for the design, manufacture, and sale of entirely new classes of devices. Based on this energy density, lithium-ion batteries are the current battery technology of choice for EVs and most consumer electronics. ${ }^{6}$ Further improving lithium-ion battery performance is a crucial enabler to achieve the outlined sustainability goals. 


\section{Introduction to lithium-ion batteries}

Since this commercial introduction 25 years ago, both industrial and academic researchers have conducted an impressive amount of work on lithium-ion battery chemistries. Encouragingly, lithium-ion battery energy storage has steadily increased, while costs have steadily decreased over the last 25 years. These benefits stem from consistent improvements in manufacturing, design, safety, and chemistry. Figure 1 shows this trend, with gravimetric energy density on the $y$-axis and volumetric energy density on the $x$-axis. ${ }^{7,8}$ The figure shows steady but incremental progress over the last $20+$ years, with an average gravimetric energy density increase of $4 \%$ per year. The concurrent decrease of cost per kilowatt-hour is shown on the right of Fig. 1.9-11 Lithium-ion batteries for EVs have recently shown an even faster reduction in cost, as they have moved from a niche application to a mass-manufactured commodity product. ${ }^{12}$

\section{Limitations of current battery commercialization model}

Large chemical companies and battery manufacturers have historically led lithium-ion battery commercialization, yet this state of affairs has significant limitations. The incremental enhancements in lithium-ion cell capacity delivered by multinational chemical companies fall dramatically short of consumer demands. ${ }^{13,14}$ One reason for these shortcomings is that original equipment manufacturers (OEMs) tend to put significant price pressure on battery suppliers, with little regard for innovation. Second, in the age of activist investors and market consolidation (see: Dow/DuPont merger), Wall Street pressures on earnings result in $R \& D$ budgets being squeezed so that only the most market-ready (incremental) approaches are explored, limiting the likelihood of step-change improvements.

The traditional commercialization model also hinders U.S. competitiveness. Because most battery manufacturers are in Asia,

\section{Annual Improvement in Energy Density}

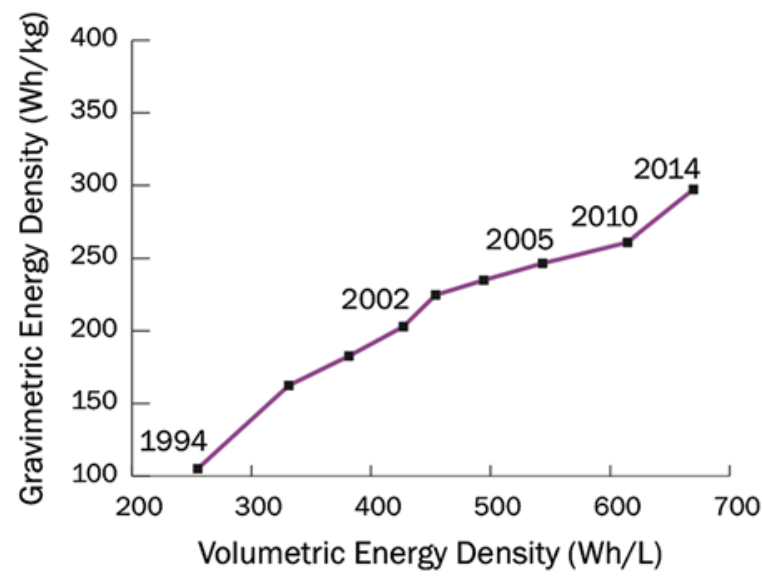

the economic benefit of U.S. battery research advances tends to be absorbed by these foreign manufacturers. Conversely, small U.S. companies and startups are challenged by the tight-margin, commoditized, large volume battery business. This situation leads to a U.S. battery commercialization gap, with a dearth of U.S. companies commercializing U.S. battery research gains. The technology transfer literature has established that both policy and market drivers impact innovation pathways. ${ }^{15,16}$ As such, we examine both the policy and market factors that hinder U.S. competitiveness.

\section{Comparisons to pharmaceutical industry}

The pharmaceutical industry has many characteristics similar to the battery industry, such as high technology risk, long timelines to success, and large capital requirements. Wall Street pressures have also squeezed big pharmaceutical R\&D programs. ${ }^{17}$ However, unlike the battery industry, the pharmaceutical industry has a vibrant commercialization ecosystem, with a healthy pipeline of startup companies developing new drugs and a variety of different sized industry players enhancing market competition. ${ }^{17}$ This enables more drugs to be explored, come to market, and ultimately help more patients, all while producing economic growth. This paper examines the particulars of both the pharmaceutical and battery industries to inform proposals for the latter via the success of the former. We provide tailored proposals to the battery industry's key stakeholders (startups, large manufacturers, investors, and policy makers) to improve commercialization outcomes. By fostering a more successful commercialization pathway for startups and small companies, we hope to encourage more entrepreneurial activity that can lead to critically important improvements in battery technology.

\section{Lithium Ion Battery Cost}

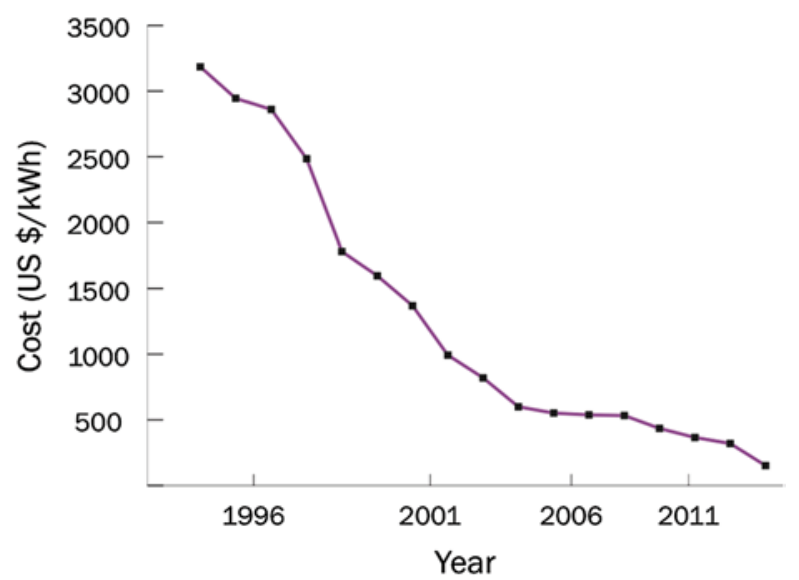

Figure 1. Over the last $20+$ years, lithium-ion battery gravimetric and volumetric energy density have gradually improved, while over the last $20+$ years, consumer electronics lithium-ion battery cost per kilowatt-hour has steadily decreased. ${ }^{10,11}$ 


\section{Materials innovation is notoriously difficult}

Commercializing new materials, both inside and outside the battery space, is notoriously challenging. This is true both for big companies and startups, but we will focus on startups in this report given the authors' focus and expertise. We analyzed a sample of 36 representative startups from the battery technology space that have received greater than $\$ 500 \mathrm{k}$ in funding and were founded after 1995, as shown in Fig. $2 .{ }^{18}$ Of these, only two have had positive exits, with returned capital that was greater than the invested capital (greater than $1 \times$ return). Only 17 of the others reached early commercialization, as indicated by pilotscale manufacturing or key corporate partnership deals; they required an average of 8 years to do so.

The challenges to battery commercialization that lead to these high failure rates include high upfront capital requirements, intellectual property (IP) barriers, and long timelines to success. These challenges derive from entrepreneurs needing to close the R\&D gap from a university lab-scale technology to a technology that is compatible with battery manufacturing techniques, while simultaneously exceeding multiple industry benchmarks. The R\&D pathway to pilot-scale battery manufacturing requires expensive labs, specialized workers, and 4-8 years of work. ${ }^{20}$ Further, to be considered meaningful by battery manufacturers and potential customers, cycle life data must be taken for months at a time. With such long iteration cycles, there are few opportunities to de-risk the technology in a meaningful way and progress takes longer to achieve. In addition, for a new material to be attractive to the market, it must match or exceed industry benchmarks across several key metrics (cycle life, energy density, electrode loading, etc.) simultaneously. These technical challenges remain formidable.
Characteristics specific to the battery market also make starting a U.S.-based small company daunting. Most importantly, the biggest target battery applications (consumer electronics, electric cars) have highly competitive, commoditized markets with only $\sim 5 \%$ operating margins over the last two years. ${ }^{21}$ OEMs put tremendous pressure on battery suppliers to reduce prices. Additionally, there are a limited number of battery redox materials found to date that have properties suitable for battery operation. As a result, the permutations of battery materials available in the near future are limited, adding to the commoditization of the industry. With such slim margins, scale is critical to make the economics work profitably, and reaching scale is both time and capital-intensive.

Another challenge to U.S. startups is that major battery manufacturers are predominately located in Asia with cheaper manufacturing capabilities. ${ }^{22}$ Since protecting IP is more challenging in many parts of Asia, trade secrets and opacity characterize the industry. ${ }^{23}$ With such secrecy about the metrics and challenges of the industry, it is difficult for startups to address pain points with appropriate specificity for battery manufacturers.

Due to the low expected profitability created by these challenges, venture investment in the battery sector is commensurately low. Recent underperformance of energy materials companies indicates that this hesitancy is appropriate. Figure 2 shows the low returns for energy materials companies and resultant venture investment declines over the last 10 years. ${ }^{19}$ Energy companies focused on materials/chemicals/processes (a parent category of battery startups) have returned only $\$ 123 \mathrm{M}$ for $\$ 764 \mathrm{M}(\sim 16 \%)$ invested over the 2004-2014 period (in other words, investors lost $84 \%$ of their invested capital). ${ }^{19}$ As a result of this poor performance, in 2013 and 2014, chemical/materials/processes energy startups received less

\section{Recent US Battery Startups}

\section{Materials/Chemical/Processes Startups}
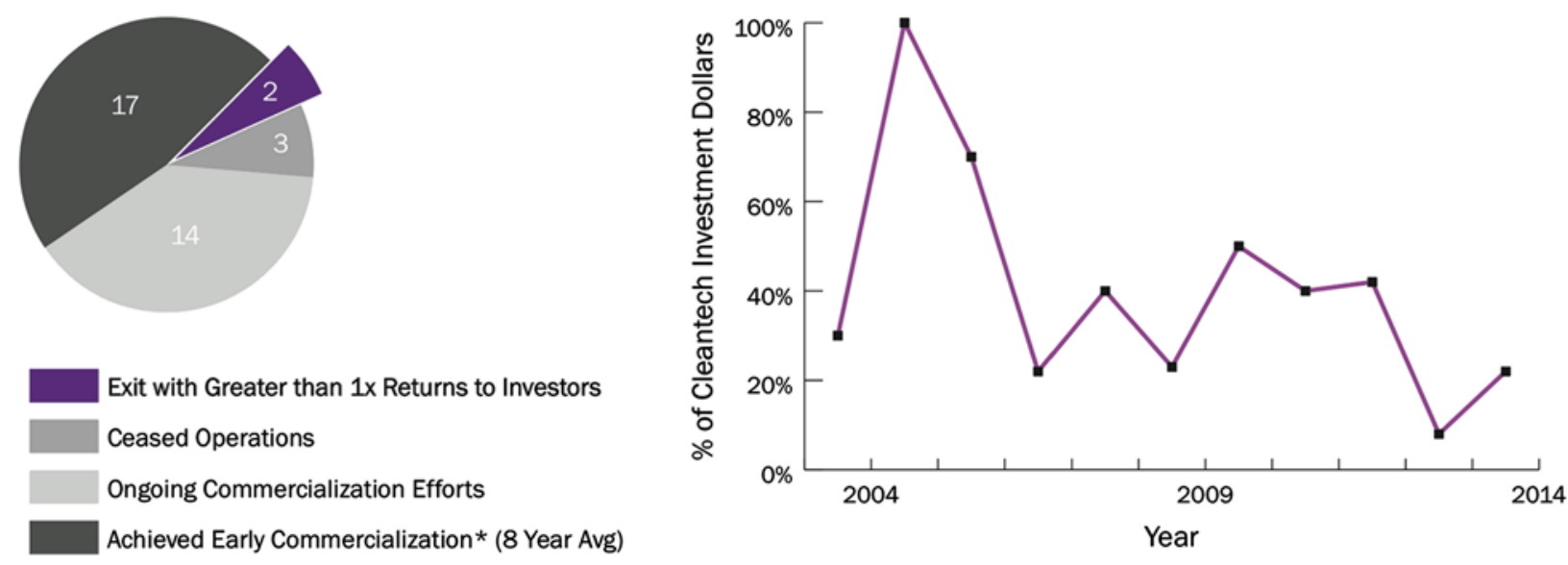

Figure 2. U.S. battery and energy materials companies have underperformed venture expectations over the last ten years. The CB Insights venture capital database lists only 36 battery technology startups with $500 \mathrm{k}+$ of investment founded since 2000 . Of these, only 2 have returned the invested capital to investors. ${ }^{18}$ As a result, Cleantech investment in energy materials/chemical/processes has declined, representing $<30 \%$ of Cleantech investment dollars in $2014 .{ }^{19}$ 
than $30 \%$ of the Cleantech investment dollars and represent only $30 \%$ of Cleantech companies receiving investment at all. ${ }^{19}$ Given such discouraging outcomes, we look to characterize the status quo and provide some suggestions to improve investment returns in the future.

\section{Traditional battery commercialization model}

There are three main techniques for improving on current lithium-ion battery specifications. (i) Processing and design, or designing the end product to utilize the battery power most efficiently. Battery manufacturers have limited control over this, given existing infrastructure investments. (ii) Mechanical improvements, like packing more active material into a given battery specification. The runway on this approach has run out and is limited by safety standards. (iii) Chemistry/materials improvements, since battery manufacturers have the most room for improvement on the chemistry side, this is where they currently focus.

The lithium-ion battery supply chain structure informs which companies focus on battery commercialization. Figure 3 shows a typical lithium-ion battery supply chain. Along the supply chain, cell component and cell assembly manufacturers typically lead the battery chemistry R\&D. Cell component manufacturers, such as Johnson Matthey, can provide a new anode or cathode material with higher performance standards to the cell assembly manufacturers. Cell assembly manufacturers, such as Samsung SDI or LG Chem, also have internal R\&D departments tasked with improving the materials and manufacturing processes. For example, Samsung SDI spent $\$ 500 \mathrm{M}+$ on R\&D in 2015 , accounting for $\sim 7 \%$ of total sales. ${ }^{31}$

The current model, which is dominated by large companies, has benefits and drawbacks. On the upside, it has brought steady improvements in lithium-ion battery energy density and performance while costs have fallen. However, these incremental improvements have not been sufficient to satisfy the more rapid growth in consumer demands for better battery performance. ${ }^{14}$

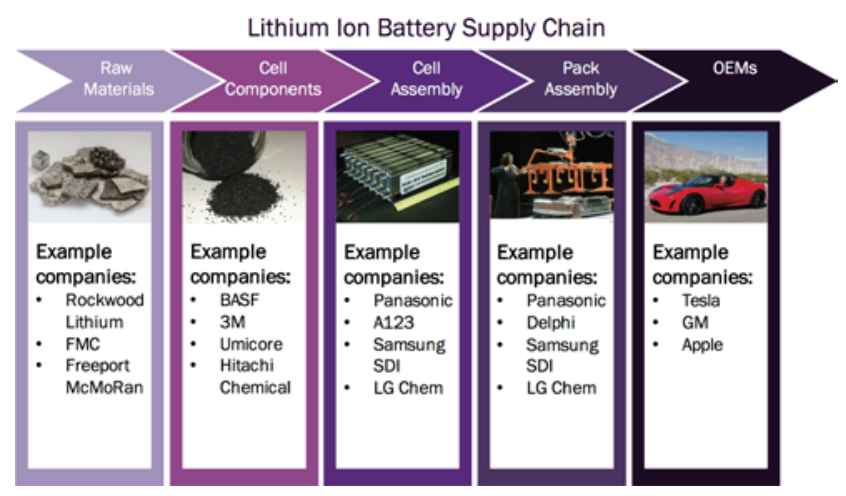

Figure 3. Typical lithium-ion battery supply chain. In the lithium-ion battery supply chain, cell components and cell assembly manufacturers typically pioneer the battery chemistry innovation. ${ }^{11,24-30}$ Images from Refs. 26-30.
With entrenched science and manufacturing methods, innovation can fall by the wayside. A classic example is the manufacturing technique used to coat electrode materials: slot die coating. Slot die coating was previously used to make cassette tapes. When Sony started to scale up the first lithium-ion battery production, they decided to use flat die coaters, because the manufacturing equipment was already available and underutilized as consumers turned to CDs over cassette tapes. ${ }^{32}$ Slot die coating is not necessarily the optimal technique to coat electrode materials, yet it is still widely adopted by the battery industry due to switching costs: it is not financially attractive for large companies to change techniques, given their invested assets. A startup, by contrast, is much less tied to existing techniques and can more economically provide the manufacturing foundation for larger performance improvements. ${ }^{32}$

The supply chain structure can also limit innovation. Since battery manufacturers generally do not have direct access to the end consumer, they cannot raise prices for a premium product. The battery manufacturers must sell to the OEMs. For the OEMs, the battery is only one component in a complex product, and price, reliability, and safety are the top concerns.

There are also financial challenges to large battery company innovation. As the industry sees more consolidation, such as the recent Dow and DuPont merger, the industry has valued the economic value of production scale more than innovation. ${ }^{33}$ Wall Street activism pushes for consistent quarterly earnings, which can result in sacrificed long-term innovation for short-term financial benefit, a pressure not felt by private startup companies. This Wall Street focus has hurt internal R\&D budgets. ${ }^{33}$

Finally, the current model tends to benefit Asian manufacturers at the expense of U.S. competitiveness. Battery research breakthroughs made by U.S. universities and national labs tend to be absorbed and commercialized by the "Big Three" battery manufacturers in Asia (LG Chem, Seoul, South Korea; Samsung SDI, Yongin-si, Gyeonggi-do, South Korea; and Panasonic, Kadoma, Osaka, Japan). We believe that the United States should be better set up to commercialize new battery technologies via U.S. startups, and reap the economic and social benefits within the United States.

\section{U.S. battery startup commercialization model}

Many U.S. startup companies have attempted to commercialize new battery materials, yet few have succeeded. Some examples include A123, 24M, Ambri, Leyden Energy, Quantumscape, and Envia Systems. The clear majority have failed to bring new technology to market in a financially sustainable (i.e., profitable) way. While a case study could be built on each of these companies and its unique challenges, there are some commonalities across these companies within the traditional venture-backed commercialization model that they shared. A few key features are the followings:

(i) Finance primarily via venture capital

(ii) Focus go-to-market plan on attacking large-scale markets $(\$ 1 \mathrm{~B}+)$ 
(iii) Seek to capture value alone (as opposed to with corporate partners)

(iv) Attempt to speed scientific progress via increased spending

(v) Raise large amounts of capital upfront $(\$ 50+\mathrm{M})$

Venture capital's demands for 5-10x returns drive this approach. While this model may work for other industries such as software, we believe that there are several reasons why this model does not work for the battery industry. First, the multiples that venture capital seeks are extraordinarily difficult to achieve in a low-margin, commoditized market. ${ }^{34}$ Second, it is exceedingly expensive to build up the manufacturing capabilities and know-how to compete with large volume incumbents. Third, there are challenges with attempting to rapidly expedite $R \& D$ efforts with large amounts of capital. In the world of software companies with a functional business model, "money in" typically yields user growth and more "money out." This principle does not apply to battery companies-more capital will not necessarily yield hastened scientific progress. For example, to improve cycle life in a given material, iteration cycles will be long because cycle life data requires months to collect, despite abundant capital. Greater capital does not necessarily speed cycle life improvements. Fourth, tales of battery technology companies raising $\$ 50-\$ 100 \mathrm{M}$ without fully de-risking fundamental chemistry barriers are abundant. By the time the companies mature, they lack a viable exit pathway to grant investors and employees liquidity. Accordingly, we believe the U.S. startup commercialization model should change.

\section{Pharmaceutical commercialization model}

The pharmaceutical startup commercialization model is well-developed, robust, and supports a large startup innovation ecosystem. Over $\$ 10 \mathrm{~B}$ venture capital dollars were invested in the medical/health/life sciences space in just 2015, across 830 deals. ${ }^{35}$ A variety of drivers lead the big pharmaceutical companies to support this innovation ecosystem. First, the high margins inherent in the pharma industry support a vibrant ecosystem. Once launched, new drugs can have gross margins of up to $\sim 90 \% .{ }^{36}$ Strict patent protection creates a built-in monopoly for novel drugs serving an unmet need/disease area, protecting these high margins. This creates demand for potential new drugs. Second, based on Wall Street pressures, big pharmaceutical companies have shrunk their internal R\&D departments. ${ }^{17}$ In-house R\&D is often used for tweaks or new indication testing on existing products, as opposed to exploring fundamentally new drugs in new disease areas. Thus, access to startup-developed drugs (via acquisitions or partnerships) is key to maintaining the company's growth and launching new products. Third, acquisitions allow big pharmaceutical companies to obtain technology, diverse experience, and relevant skills relatively cheaply, versus trying to build up those capabilities on their own.

Figure 4 shows pharma acquisition values by FDA phase between 2005 and $2012 .{ }^{17}$ Based on the large margins and

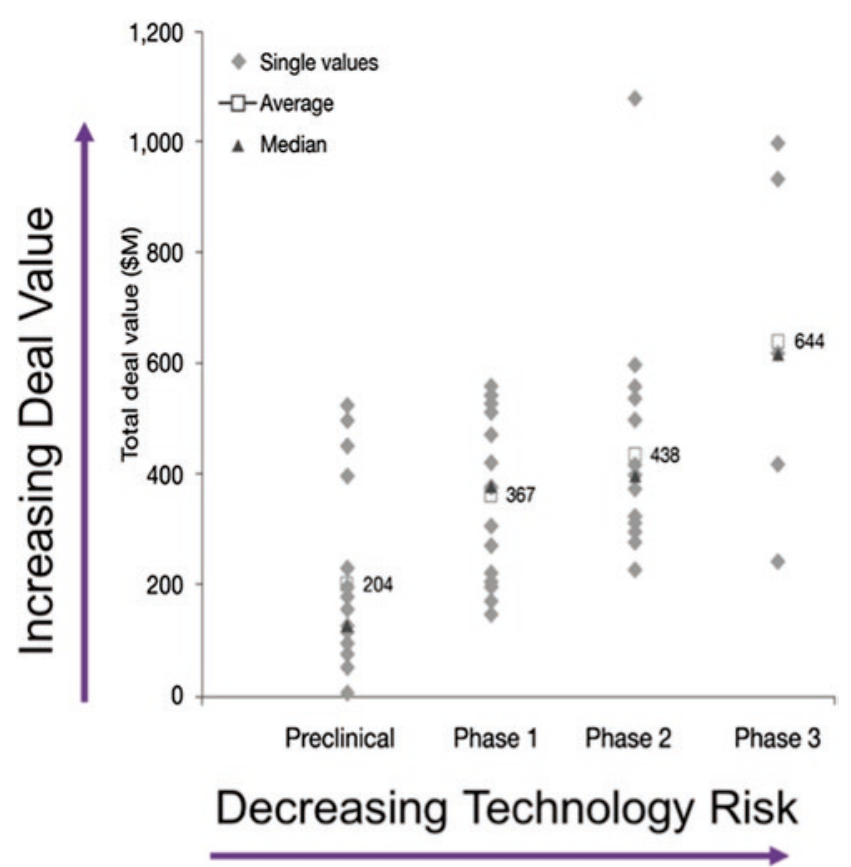

Figure 4. Deal sizes of pharmaceutical startup acquisitions between 2005 and 2012. Adapted by permission from Macmillan Publishers Ltd: Nature Biotechnology (17), copyright (2013).

potential profit values, the acquisition deal values are substantial: often, in the hundreds of millions. The FDA clinical development phases serve as benchmarks for the company's technical progress. Each clinical development phase requires meeting or exceeding increasingly complex clinical endpoints to continue in the process toward market approval. This system implies that a company has increasingly de-risked its technology, and its value often improves accordingly. It is important to note that all the acquisitions shown in the figure are pre-revenue and that acquisitions occur at each stage along the R\&D development pathway.

Within the pharmaceutical market, a robust ecosystem of mergers \& acquisitions (M\&A) activity has developed. Conferences hold formal meet and greet events for startups and big pharmaceutical companies. ${ }^{37}$ Pharmaceutical companies market their target partnering and acquisition areas via dedicated websites and business development brochures. ${ }^{17}$ Acquisitions and strategic investments are widespread enough to have developed a variety of complex deal terms. ${ }^{38}$ FDA-forced transparency in the marketplace further benefits the M\&A ecosystem. The FDA now requires that clinical trial data be published publicly. ${ }^{39,40}$ This allows investors or potential acquirers to have broad access to relevant data. That access enables them to examine the most critical scientific data and ultimately further de-risk a potential investment. Many venture capital funds focus on life sciences/pharmaceutical investments, with scientific experts performing detailed diligence on candidate companies' fundamental science. ${ }^{41}$ Together, these industry characteristics make pharmaceutical an attractive industry for startup innovation. 


\section{Applying lessons from the pharma model to battery innovation}

In this section, we propose changes to the battery startup commercialization model based on the pharma innovation model. We will then address the potential pitfalls of the proposed approach and arrive at final recommendations.

\section{Proposals for entrepreneurs}

\section{R\&D strategy}

Inspired by the pharmaceutical model, we recommend that entrepreneurs focus on customer-led performance metrics as early as possible. A frequent mistake in battery startups is to confuse academic figures of merit for industry-set figures of merit. For example, academic research tends to focus on initial figures of merit (such as energy density), novelty, or mechanism rather than accelerated testing or commercial compatibility. By contrast, industry requires high energy density concurrent with long cycle life, high electrode loading, and other factors. At the minimum, sending samples to customers to receive early testing and feedback is highly advantageous and helps ensure that startup R\&D efforts are working against a market-driven goal. Joint development agreements can also help ensure that entrepreneurs focus on the appropriate industry metrics. In the pharmaceutical industry, joint development agreements are common, complementing the startup's technology with large company resources and ensuring industry validation. For better chances of success, we recommend battery startups look for corporate partnerships and joint development agreements to leverage the resources and market know-how of large company partners. There are a few early examples of U.S. startups leveraging large company resources; XG Sciences has a partnership with Samsung SDI to develop anode materials, ${ }^{42}$ while $24 \mathrm{M}$ and NEC have partnered to commercialize grid-scale storage systems. As part of the agreement, NEC is testing $24 \mathrm{M}$ products. This provides crucial industry validation, which raises $24 \mathrm{M}$ 's credibility with customers and potential acquirers. ${ }^{43}$

\section{Fundraising}

Due to misalignment between venture capital expectations and battery market realities, we recommend entrepreneurs look for nontraditional sources of capital. This could include government grants (ARPA-E research grants, SBIR grants), corporate partnership research dollars, or philanthropic capital. Venture capital may be sought, but entrepreneurs should recognize that venture capital expectations may not be well aligned with the battery market's realities.

Successful entrepreneurs are realistic about exit opportunities and fundraise strategically to make exits meaningful. In the pharmaceutical industry, acquisitions happen all along the commercialization chain, with more developed drugs receiving higher acquisition values. There are similar opportunities in the battery space: a battery startup does not need to hit full manufacturing production to be valuable. However, exits in the battery space tend to fall into two categories: IP-driven exits that are less than $\$ 10 \mathrm{M}$ and manufacturing/asset-driven exits that are greater than $\$ 50 \mathrm{M}$. In the past, these exits have not been particularly lucrative. Many IP-focused companies will raise over $\$ 20 \mathrm{M}$, overcapitalizing potential exits (e.g., Leyden Energy). To be prudent, entrepreneurs should take on modest amounts of capital and apply it very strategically to the most critical, market-driven R\&D, and sales efforts. In the pharmaceutical industry, entrepreneurs generally fundraise according to their FDA phase of development. Similarly, battery entrepreneurs should recognize their end goal-if they do not plan to go into large-scale manufacturing, then capitalization must remain modest $(<\$ 20 \mathrm{M})$ if they are to generate incremental value from technology sale or licensing. We recognize that building complex battery technology requires significant effort and funding, so the challenge for entrepreneurs will be attracting nondilutive sources of funding to keep the capital profile of the company attractive for potential licensors, partners, and buyers.

\section{Application selection}

We recommend that battery entrepreneurs attack higher margin, niche applications first. Such beachhead or small target markets are critical to gathering customer revenue and feedback faster for new battery technologies. The biggest emerging battery markets, such as automotive EVs, have prohibitively long timelines to success. Even after hitting full battery production scale $(10+$ year process $)$, there is a $7-10$ year process of becoming a new technology supplier in the auto industry. ${ }^{13}$ These timelines will kill any startup looking for revenue. Accordingly, we recommend that new battery startups look for initial niche applications that take advantage of unique performance capabilities of their technology. This will bring in revenue sooner and help prove out the technology. One good example of this strategy is the Canadian battery startup Corvus Energy. Corvus Energy focuses on largeformat batteries for marine applications and has shown strong revenue growth over the past five years. ${ }^{44}$ Another example lies in A123, which successfully commercialized new cathode materials for the power tool market within seven years of leaving the academic lab benchtop. A123 also proves an informative example in the converse case, as management decided to immediately move on to the automotive market without a middle-term market, and plunged into bankruptcy when demand for EVs slowed and their batteries were part of a recall. ${ }^{45,46}$ We believe attacking a beachhead market first and growing conservatively increases a startup's chances of building a profitable business.

\section{Proposals for venture capital investors}

We recommend that venture capitalists approach the battery industry with caution. We recommend developing scientific benches of industry and academic researchers, similar to pharmaceutical investors, to vet the science of prospective companies. Venture capital funds should also incorporate long time horizons into investment models to more realistically price battery startup companies.

We believe that interested investors will benefit from using common metrics to evaluate new battery companies. To provide 
a preliminary framework for evaluating early stage battery companies, we propose the benchmarks in Fig. 5. These metrics can help benchmark a new company's progress and valuation.

\section{Proposals for component and cell assembly manufacturers}

It is in large battery manufacturing companies' interest to foster a healthier startup ecosystem. This allows for more R\&D ideas to be vetted and tested outside of corporate R\&D. With that in mind, we recommend that large companies leverage joint development agreements and startup partnerships more widely. This allows large companies to gain a window into cutting-edge research with relatively low risk. It also helps build the pipeline for future performance improvements by tapping into startups' R\&D potential; these performance improvements are critical in such a competitive industry.

As seen in the pharmaceutical industry, transparency (e.g., via publishing trial data and setting endpoint requirements) can help the innovation ecosystem work more efficiently to both large and small companies' benefit. To help the startup ecosystem be more efficient and targeted toward manufacturers' R\&D goals, battery manufacturers should widely release their key performance testing metrics. Battery companies should also present grand technical challenges for innovators, both in university and startup settings. Together, these initiatives would allow current

\section{PHARMA}

$\begin{array}{cc}\text { Preclinical and animal model studies } & \text { Phase II Trial } \\ <\$ 20 M & \$ 50-100+\mathrm{M} \\ \text { Cell data, animal } & \text { Efficacy and side } \\ \text { model data } & \text { effects are shown with } \\ \text { shows efficacy } & \text { larger human trial (up } \\ \text { and safety } & \text { to a few hundred } \\ & \text { people) }\end{array}$

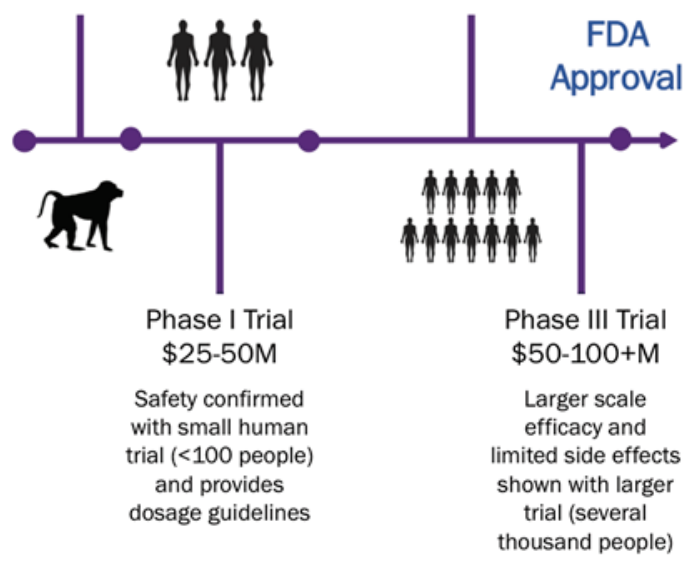

academic and startup R\&D efforts be more efficiently focused toward solving today's critical battery challenges.

\section{Proposals for OEMs}

Building off our proposals for battery manufacturers, we recommend that OEMs also support commercialization joint development agreements and partnerships. OEM products, particularly battery-dependent products such as EVs, will be limited if battery innovation falters. However, battery innovation is not always a supply chain focus. Joint development agreements that bring together the innovative startup, battery manufacturer, and OEM will be most successful at commercializing new battery technologies to full market adoption. Policy makers can help foster these partnerships via consortia that bring together the relevant stakeholders, such as the U.S. Advanced Battery Consortium (USABC).

\section{Proposals for policy makers}

Given the social good brought about by improved battery performance but current market shortcomings, we believe the battery startup ecosystem is a prime target for intelligent government support. We have segmented out the potential policy support by battery startup development milestone.

\section{BATTERIES}

\section{Benchtop to Half Cell data* 3rd Party Validated Full Cell** $<\$ 3 \mathrm{M}$ \\ Active materials capacity, cycle life, initial and average Coulombic efficiency, electrode loading meets or exceeds \$5-15M \\ Cell capacity, implied energy density, cycle life, initial and average Coulombic efficiency, electrode loading meets or exceeds industry standard} industry standard

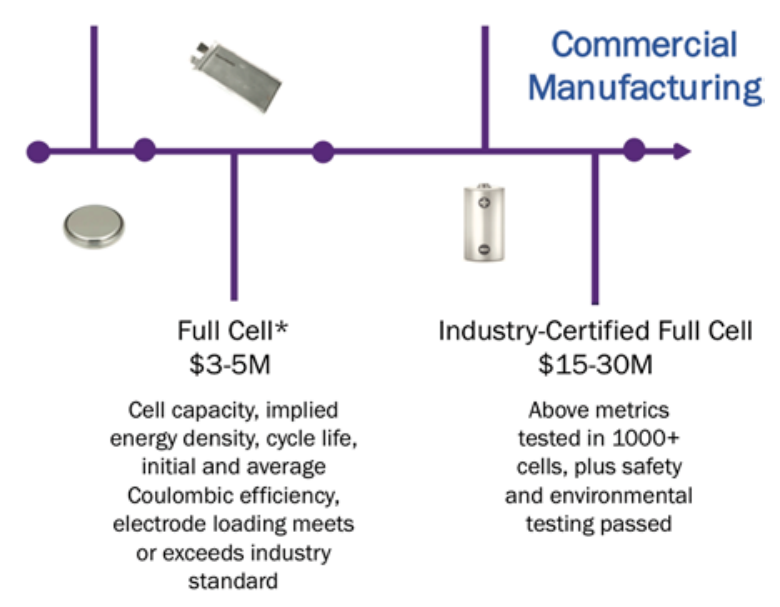

* From coin and small pouch cells

**Material tested in industry standard cell (e.g. 18650)

Figure 5. Proposed battery technology phases and metrics for investor evaluation of startup company progress. 


\section{Benchtop to half-cell stage}

The government should build additional support for early stage startup technical development due to the dearth of private investment. This could take place as financial support, perhaps via larger SBIR budgets with larger grants. It also could take the form of in-kind services, such as accelerator programs within national labs, to provide lab space, expertise and instruments to allow new companies to build their technical knowhow. The DOE is currently piloting several programs of this kind, including Cyclotron Road and Chain Reaction Innovation. ${ }^{47}$ We encourage these efforts.

\section{Full cell stage}

Downstream grants, such as applied research SBIR grants, would be most beneficial at this stage to accelerate markettargeted technical development. The new DOE Small Business Voucher Program is a good example of a policy initiative that can accelerate full cell battery testing and should be expanded. Additionally, prototyping centers across the country should be the target of new government funding mechanisms to support early-stage technologies. Examples of such centers include the Battery Innovation Center in Indiana and Polaris Battery Labs in Oregon. Such targeted government support can accelerate startups' technical progress.

\section{3rd party validated full cell}

The government currently certifies battery results, at institutions such as Crane or Argonne National Laboratory. Subsidized fees for startups and small companies would be an easy way for the government to help U.S. startups achieve certified research results. Government battery testing helps startups certify their performance data, de-risking their technology.

\section{Industry-certified full cell}

By this point, government support could be limited. We recommend that government support be focused during early stages of development to help de-risk the technology. As the startup is de-risked, private and strategic dollars should be easier to attract.

We hope that implementation of these ideas can aid startup success rates in the battery industry, resulting in more innovative technical development.

\section{Potential pitfalls}

While we believe that these recommendations are sound, it is important to note the pitfalls of this analogical reasoning. The most important difference between the pharmaceutical and the battery markets are the differences in margins $(\sim 90 \%$ compared to $<5 \%$ ). Big pharmaceutical companies' continued success results in larger venture investment, more partnerships, and greater acquisition dollars for pharmaceutical startups as compared to battery startups. Pharmaceutical venture investment is currently ten times larger than energy materials/chemical/ processes investment.

Figure 6 shows the 2015 average operating margins, $2015 \mathrm{R} \& \mathrm{D}$ as a percent of revenue, and average time to early manufacturing/commercialization (not profitability) for the battery and pharmaceutical markets. The pharmaceutical industry's high margins can lead to higher R\&D budgets as a \% of revenue and greater investment in the innovation ecosystem. However, the battery and pharmaceutical industry both experience long timelines to success driven by scientific challenges; it takes 12 years on average to move a new drug from discovery through final FDA approval and market launch. ${ }^{54}$ The pharmaceutical industry also experiences high clinical trial failure rates (less than $1 \%$ of phase one candidates make it to market) with higher risk consequences (drug complications, death). ${ }^{55}$ Based on our analysis, it takes battery startups an average of 8 years to achieve early commercialization/pilot manufacturing. Other sources have estimated the timeline of integrating a new material into the battery market as between 10 and 20 years. ${ }^{11}$ The key challenge of the battery industry, especially as compared to the pharmaceutical industry, lies in overcoming the large scientific barriers with lower economic rewards for success.

\section{Recommendations in practice_-SiNode Systems case study}

SiNode Systems is an early-stage battery materials venture that recognizes the parallels between technology development in life and physical sciences. SiNode is commercializing a novel silicon anode technology based on research from Northwestern University, and the company has maintained a lean capital profile (raising only a seed financing round) since incorporating in 2013. SiNode has secured pilot customers in niche consumer electronics markets, and it has launched strategic partnerships with top-tier materials companies, battery manufacturers, and device OEMs. SiNode's partnerships with multiple OEMs (both in short-term niche markets and longer-term markets such as automotive) have accelerated commercialization of the company's anode technology. By working directly with OEMs, SiNode has gained leverage over its supply chain and formed partnerships with battery manufacturers recommended by the OEMs. The OEM relationships have opened the door to new sources of funding and supply chain partnerships that have significantly reduced SiNode's technical and scale-up risk. In addition, the company has received nondilutive funding from the U.S. Government's SBIR program and other public sources, including the USABC. The SiNode experience offers a case study in building value from strong technology partnerships, lean capitalization, and nondilutive funding.

\section{Conclusions}

Higher energy density and lower-cost lithium-ion batteries are critical to a carbon-neutral future. Yet, there are daunting technical and market hurdles to bringing the advanced materials required for better battery performance to market. As a result, despite the United States' world-leading academic battery research, most battery commercialization over the last 25 years has come from incremental advances implemented by large international battery companies. To address this U.S. battery commercialization gap, we examine the status quo of 


\section{Average Net Margins}

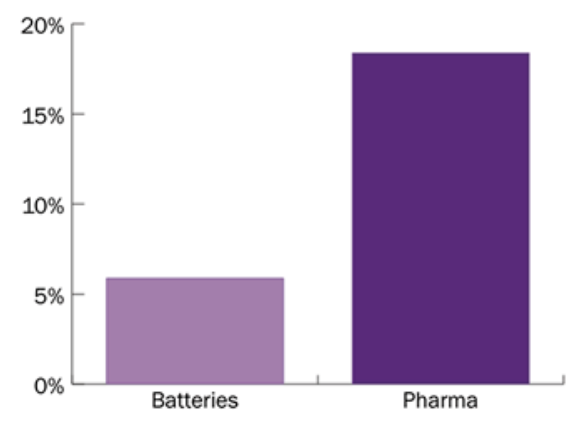

\section{R\&D as Percent \\ of Revenue}

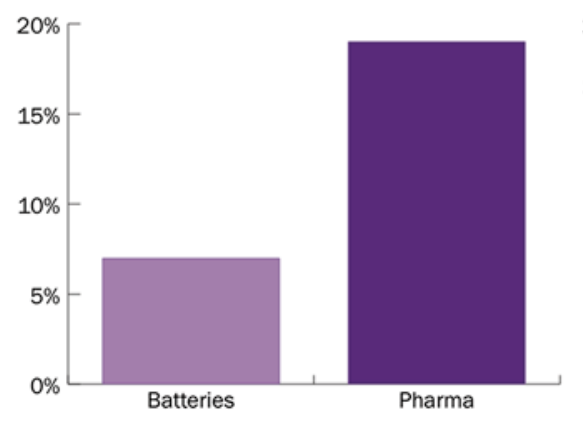

\section{Average Time to Early Manufacturing}

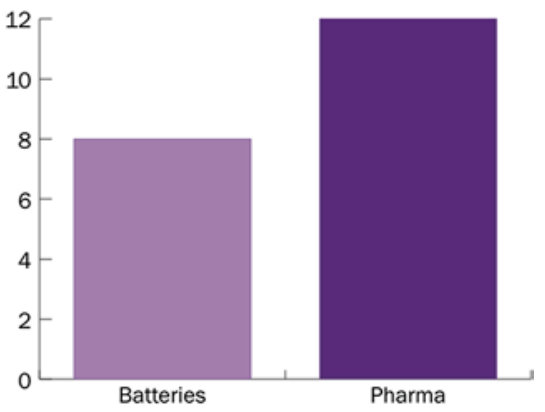

Figure 6. F500 Pharmaceutical companies have significantly higher margins than F500 battery companies, which allows them to spend more on R\&D. However, the scientific challenges of bringing a battery or a new drug to market, represented by time to manufacturing, are similar. $7,18,48-54$

battery commercialization. Interestingly, the pharmaceutical industry has many similar technical hurdles to the battery industry but has a robust startup innovation ecosystem. We take inspiration from the pharma model's successes to inform suggestions to improve the battery innovation ecosystem. We identify elements of the pharma model's success that apply to the battery industry and provide tailored proposals to entrepreneurs, investors, large battery companies, and policy makers. Together, we hope that these ideas spur the battery ecosystem to more successfully commercialize transformative battery technologies.

\section{Acknowledgments}

This material is partially based upon work supported by the National Science Foundation under Grant No. DMR-1507810, and by the U.S. Department of Energy, Office of Science, Office of Basic Energy Sciences, under Award Number DE-SC0014520. Research also supported as part of the Center for Electrochemical Energy Science, an Energy Frontier Research Center funded by the U.S. Department of Energy (DOE), Office of Science, Basic Energy Sciences (BES), under Award \# DEAC02-06CH11357 (for paper conception). The authors thank Max Hardage for his U.S. battery startup analysis and Dean de la Peña for copy editing. The authors would like to thank many professionals who gave keen insight into their industries. The recommendations provided, and any mistakes within the manuscript, are wholly the authors'. The authors thank (in alphabetical order) Faruk Abdullah, Keith Crandell, Brendan Florez, Jim Greenberger, Supratik Guha, Benjamin Hernandez, David Klein, Matthew Nordan, Leslie Pinnell, Andreas Roelofs, Amar Shah, Deepa Sheth, and Donna Williamson, among others.

\section{REFERENCES:}

1. EV Everywhere Grand Challenge Blueprint, Vol. 31 (Department of Energy, 2013). Available at: https://energy.gov/sites/prod/files/2014/02/f8/ eveverywhere_blueprint.pdf (accessed August 18, 2017).

2. Gaines L. and Cuenca R.M.: Costs of Lithium-Ion Batteries for Vehicles (Argonne National Laboratory, Argonne, IL USA, 2000).
3. Inventory of US greenhouse gas emissions and sinks, 1990-2014. EPA, Ed. EPA 430-R-16-002, 2016.

4. Elliott D.: A balancing act for renewables. Nat. Energy 1, 15003 (2016).

5. van Schalkwijk W. and Scrosati B.: Advances in Lithium-Ion Batteries (Springer Science \& Business Media, New York, NY, 2007).

6. Voelcker J.: Electric-car battery costs: Tesla $\$ 190$ per kwh for pack, GM $\$ 145$ for cell (2016). Available at: http://www.greencarreports.com/ news/1103667_electric-car-battery-costs-tesla-190-per-kwh-for-pack-gm145-for-cells (accessed March 10, 2017).

7. $\quad$ Pillot C.: The Worldwide Rechargeable Battery Market 2012-2025 (Avicenne Energy, Nice, France, 2013); p. 67.

8. Mayekar S.: Bringing New Battery Technology to Market: Crossing the Chasm (Sinode Systems, Lemont, IL, 2015).

9. Crabtree G., Kócs E., and Trahey L.: The energy-storage Frontier: Lithium-ion batteries and beyond. MRS Bull. 40, 1067-1078 (2015).

10. Arora A., Buckland R., Buiter W., D’Antonio P., Ding S., Edwards R., Elliot R. Fordham T., Goldin I., Hale J., Horowitz K., Iizuka N., Lee E., Lee W., Levkovich T., Lorenzen H., Lubin D., Menuet G., Morse E., Morse R., Murashima K., Peterson D., Pitt A., Rahbari E., Sasaki T., Saunders M., Savvantidou S., Schofield M., Shen M., Shoup J., Spittle M., and Yuen A.: Investment Themes in 2015: Dealing with Divergence (Citi GPS, 2015); p. 54

11. Pillot C.: The Rechargeable Battery Market and Main Trends 2015-2025, Lithium Battery International Summit, Shenzhen, China (Avicenne Energy, Shenzhen, China, 2016).

12. Nykvist B. and Nilsson M.: Rapidly falling costs of battery packs for electric vehicles. Nat. Clim. Change 5, 329-332 (2015).

13. Franco G.G.: Advanced and post lithium-ion batteries 2016-2026: Technologies. In Markets, Forecasts-Silicon Anode, Solid-State, Sulphur, Lithium-Air, Sodium-Ion and Magnesium batteries, and Lithium Capacitors (IDTechEx, 2015). Available at: http://www. idtechex.com/research/reports/advanced-and-post-lithium-ionbatteries-2016-2026-technologies-markets-forecasts-000449.asp (accessed August 18, 2017).

14. 10 Hot Consumer Trends 2016, Erricsson Consumer Lab, 2015.

15. Stephan A., Schmidt T.S., Bening C.R., and Hoffmann V.H.: The sectoral configuration of technological innovation systems: Patterns of knowledge development and diffusion in the lithium-ion battery technology in Japan. Res. Policy 46, 709-723 (2017).

16. Kirchberger M.A. and Pohl L.: Technology commercialization: A literature review of success factors and antecedents across different contexts. J. Technol. Transfer 41, 1077-1112 (2016).

17. Giniatullina A., Boorsma M., Mulder G-J., and van Deventer S.: Building for big pharma. Nat. Biotechnol. 31, 284-287 (2013).

18. Venture Capital Database, Insights, C., 2016. Available at: https://www. cbinsights.com/venture-capital-database (accessed August 18, 2017). 
19. Gaddy B.E., Sivaram V., Jones T.B., and Wayman L.: Venture capital and cleantech: The wrong model for energy innovation. Energy Policy 102, 385-395 (2017).

20. Laslau C.: What It Really Costs to Commercialize New Battery Technology: Lessons From More than a Decade of Investment Data (Luxresearch, 2016). Available at: https://members.luxresearchinc.com/research/report/20491 (accessed August 18, 2017).

21. Ciez R.E. and Whitacre J.F.: The cost of lithium is unlikely to upend the price of Li-ion storage systems. J. Power Sources 320, 310-313 (2016).

22. Lacey S.: Stem CTO: Lithium-ion battery prices fell $70 \%$ in the last 18 months. Available at: https://www.greentechmedia.com/articles/read/ stem-cto-weve-seen-battery-prices-fall-70-in-the-last-18-months (accessed March 10, 2017).

23. Best Practices: Intellectual property protection in China (2016). Available at: https://www.uschina.org/reports/best-practices-intellectual-propertyprotection-china/ (accessed March 10, 2017).

24. Research N.: Materials for advanced batteries (2016). Available at: https:// www.navigantresearch.com/research/materials-for-advanced-batteries (accessed March 10, 2017).

25. Chung D., Elgqvist E., and Santhanagopalan S.: Automotive lithium-ion cell manufacturing: Regional cost structures and supply chain considerations. Contract 303, 275-3000 (2016).

26. Cobalt (2017). Available at: https://en.wikipedia.org/wiki/Cobalt-/media/ File:Kobalt_electrolytic_and_1cm3_cube.jpg (accessed March 14, 2017).

27. Black Powder (2017). https://commons.wikimedia.org/wiki/File:Black_ Powder-1.JPG (accessed August 8, 2017).

28. Prototype of 75 watt-hour lithium-ion polymer battery (2017). https:// en.wikipedia.org/wiki/Electric_car\#/media/File:NASA_Lithium_Ion_ Polymer_Battery.jpg (accessed August 8, 2017).

29. Chevy Volt First Battery (2017). https://commons.wikimedia.org/w/ index.php?curid=36091953 (accessed August 8, 2017).

30. Tesla Roadster 2.5 (2017). https://commons.wikimedia.org/wiki/ Category:Tesla_Roadster\#/media/File:Roadster_2.5_windmills.jpg (accessed August 8, 2017).

31. Samsung SDI Research \& Development (2016). Available at: http://www. samsungsdi.com/about-sdi/research-development.html (accessed February 5, 2017).

32. LeVine $\mathrm{S}$.: The story of the invention that could revolutionize batteries-and maybe American manufacturing as well (2015). Available at: http://qz.com/433131/the-story-of-the-inventionthat-could-revolutionize-batteries-and-maybe-americanmanufacturing-as-well/ (accessed February 5, 2017).

33. Parrish M.: How the Dow-DuPont Merger Will Impact the Chemicals Industry (2016). Available at: http://www.chem.info/article/2016/03/ how-dow-dupont-merger-will-impact-chemicals-industry (accessed February 5, 2017).

34. Hogg S.: Why So Many VC Firms Invest in the Same Companies (2013). Available at: https://www.entrepreneur.com/article/227144 (accessed February 5, 2017).

35. Association, N. V. C.: NVCA yearbook, Thomson Financial Venture Economics, 2015.

36. Gilead Sciences Announces First Quarter 2016 Financial Results (2016). Available at: http://www.gilead.com/news/press-releases/2016/4/ gilead-sciences-announces-first-quarter-2016-financial-results (accessed February 5, 2017).
37. BioPharm America (2016). Available at: https://ebdgroup.knect365.com/ biopharm-america/ (accessed February 5, 2017).

38. Eheman K.E. Jr.: Planning for the exit. Nat. Biotechnol. 30, 132-134 (2012).

39. Brennan Z.: Final Rule on Clinical Trial Transparency: Will it be Enough to Encourage More Compliance? (2016). Available at: http://raps.org/ Regulatory-Focus/News/2016/09/16/25867/Final-Rule-on-Clinical-TrialTransparency-Will-it-be-Enough-to-Encourage-More-Compliance/ (accessed February 5, 2017).

40. ClinicalTrials.gov (2016). Available at: https://clinicaltrials.gov/ (accessed February 5, 2017).

41. Martino M. and Myers C.: Top Venture Capital Firms. Available at: http://www.fiercebiotech.com/special-report/top-venture-capitalfirms (accessed February 5, 2017).

42. Samsung invests in XG Sciences, to co-develop graphene-based batteries (2014). Available at: http://www.graphene-info.com/samsung-invests-xgsciences-co-develop-graphene-based-batteries (accessed February 5, 2017).

43. 24M Delivers Initial Quantity of Production-size Semisolid Lithium-ion Cells to NEC Energy Solutions for Testing and Validation. 24M, 2016.

44. Pentland W.: Canadian Battery Startup is Succeeding Where U.S. Startups Have Mostly Failed (2015). Available at: http://www.forbes.com/sites/ williampentland/2015/11/16/canadian-battery-startup-is-succeedingwhere-u-s-startups-have-mostly-failed/-34e79ea6c9cd (accessed February 5, 2017).

45. Key Dates in A123 Systems History (2012). Available at: https://www. bostonglobe.com/business/2012/10/16/key-dates-systems-history/ b1L4ec7Hjp2DYExc1spOEN/story.html (accessed February 5, 2017).

46. Gereffi G., Trigg T., and Lowe M.: Case Study: A 123 Systems Local Markets and Competitiveness a Value Chain Analysis (Duke University, Durham, NC, 2010). Available at: http://www.cggc.duke.edu/pdfs/ CGGC_A123_CaseStudy_10-22-10.pdf (accessed August 18, 2017).

47. Chain Reaction Innovation is DOE's Newest Investment in the Clean Energy Innovation Ecosystem (2016). Available at: https://energy.gov/ eere/amo/articles/chain-reaction-innovation-doe-s-newest-investmentclean-energy-innovation (accessed March 12, 2017).

48. Damodaran A.: Margins by Sector (US). NYU Stern, 2016.

49. Spending of U.S. pharmaceutical industry for research and development as a percentage of total revenues from 1990 to 2015 (2016). Available at: https://www.statista.com/statistics/265100/us-pharmaceutical-industryspending-on-research-and-development-since-1990/ (accessed February 5 , 2017).

50. Expected global market share of lithium battery makers in 2016. Statistica, 2016.

51. Panasonic Annual Report 2014 (Panasonic Corporation, 2014); p. 2. Available at: https://www.panasonic.com/global/corporate/ir/pdf/ panasonic_ar2014_e.pdf (accessed August 18, 2017).

52. SDI, S.: Research \& Development (2016). Available at: http://www. samsungsdi.com/about-sdi/research-development.html (accessed March 5, 2017).

53. LG CHEM Annual Report 2015, LG Chem, 2015.

54. Fact Sheet: New Drug Development Process, California Biomedical Research Association.

55. Waring M.J., Arrowsmith J., Leach A.R., Leeson P.D., Mandrell S., Owen R.M., Pairaudeau G., Pennie W.D., Pickett S.D., Wang J., Wallace O., and Weir A.: An analysis of the attrition of drug candidates from four major pharmaceutical companies. Nat. Rev. Drug Discovery 14, 475-486 (2015). 